\title{
Hypoxia Inducible Factors Modulate Mitochondrial Oxygen Consumption and Transcriptional Regulation of Nuclear-Encoded Electron Transport Chain Genes
}

\author{
Hye Jin Hwang, ${ }^{\dagger, \S}$ Scott G. Lynn, ${ }^{\dagger, \ddagger}, \|$ Ajith Vengellur, ${ }^{\dagger}$ Yogesh Saini, ${ }^{\dagger, \ddagger}$ Elizabeth A. Grier, ${ }^{\dagger}$
} Shelagh M. Ferguson-Miller, ${ }^{\dagger,}$ and John J. LaPres $*, \dagger, \$$

${ }^{\dagger}$ Department of Biochemistry and Molecular Biology, ${ }^{\ddagger}$ Center for Integrative Toxicology, and ${ }^{\S}$ Center for Mitochondrial Science and Medicine, Michigan State University, East Lansing, Michigan 48824-1319, United States

\section{Supporting Information}

ABSTRACT: Hypoxia inducible factor-1 (HIF1) is a stress-responsive nuclear transcription factor that is activated with a decrease in oxygen availability. HIF1 regulates the expression of genes involved in a cell's adaptation to hypoxic stress, including those with mitochondrial specific function. To gain a more comprehensive understanding of the role of HIF1 in mitochondrial homeostasis, we studied the link between hypoxia, HIF1 transactivation, and electron transport chain (ETC) function. We established immortalized mouse embryonic fibroblasts (MEFs) for HIF $1 \alpha$ wild-type (WT) and null cells and tested whether HIF $1 \alpha$ regulates mitochondrial respiration by modulating gene expressions of nuclear-encoded ETC components. Highthroughput quantitative real-time polymerase chain reaction was performed to screen nuclearencoded mitochondrial genes related to the ETC to identify those whose regulation was HIF1 $\alpha$ dependent. Our data suggest that $\mathrm{HIF} 1 \alpha$ regulates transcription of cytochrome $c$ oxidase $(\mathrm{CcO})$ heart/muscle isoform 7al (Cox7a1) under hypoxia, where it is induced 1.5-2.5-fold, whereas Cox4i2 hypoxic induction was HIF $1 \alpha$-independent. We propose that adaptation to hypoxic stress

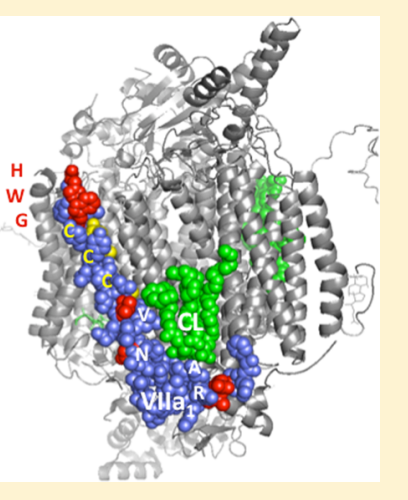
of $\mathrm{CcO}$ as the main cellular oxygen consumer is mediated by induction of hypoxia-sensitive tissue-specific isoforms. We suggest that $\mathrm{HIF} 1$ plays a central role in maintaining homeostasis in cellular respiration during hypoxic stress via regulation of $\mathrm{C} c \mathrm{O}$ activity.

$\mathrm{H}$ ypoxia is defined as a state in which the level of oxygen drops below normal in cells or tissues. ${ }^{1}$ Hypoxia causes stress within a cell that disrupts homeostasis, and these hypoxiainduced disruptions are associated with all of the leading causes of death in the United States, including cardiovascular disease, strokes, and cancer. ${ }^{2,3}$ Because of the detrimental effects of decreased oxygen tension, primarily at the level of energetics, organisms have developed a programmed response to this condition. ${ }^{4}$ This response is predominantly aimed at increasing the level of glucose utilization at the cellular level and the stimulation of erythropoiesis and angiogenesis at organismal levels. $^{2}$ This occurs primarily through the transcriptional regulation of genes involved in these processes, such as those for glycolytic enzymes and transporters (Gapdh and Slc2al), erythropoietin (Epo), and vascular endothelial growth factor $(V e g f a)$. The transcriptional response to hypoxia is primarily regulated by a subset of the PAS superfamily of proteins, the hypoxia inducible factors. 1,2

Hypoxia inducible factors (HIFs), which include HIF $1 \alpha$, HIF2 $\alpha$, HIF $3 \alpha$, aryl hydrocarbon receptor nuclear translocator (ARNT, also known as HIF1 $\beta$ ), and ARNT2, are transcriptional regulators whose activity is sensitive to decreases in oxygen availability. ${ }^{2,3}$ HIF $1 \alpha$, HIF $2 \alpha$, and HIF $3 \alpha$ are primarily cytoplasmic and, under normal oxygen tension conditions, are quickly degraded by the ubiquitin pathway. This degradation is dependent upon protein motifs, termed oxygen-dependent degradation domains (ODDs), found near the carboxy terminus of the protein. ${ }^{2}$ The hydroxylation of conserved residues within the ODD by oxygen-requiring prolyl hydroxylase domain-containing proteins (PHDs) targets HIFs for proteasomal degradation. Under hypoxic conditions, HIFs are stabilized and translocate to the nucleus where they are free to form dimers with ARNT or ARNT2. These heterodimers bind genomic DNA at sites called hypoxia response elements (HREs) to modulate transcription. ${ }^{2}$ Though HIFs are the primary mediators of the cellular response to hypoxic stress, HIF-independent signaling pathways also play a significant role following exposure to low levels of oxygen.,

Hypoxia directly impacts mitochondrial function by limiting the availability of oxygen necessary to complete the electron transport chain (ETC). Mitochondria utilize approximately $90 \%$ of cellular oxygen and, in return, generate approximately $90 \%$ of the total cellular energy (ATP) in normal tissues. ${ }^{7,8}$ Aerobic respiration involves three distinct phases: oxidation of substrates (e.g., glucose), electron transport, and oxidative phosphorylation (OXPHOS). In this process, reducing equivalents, primarily derived from the tricarboxylic acid

Received: October 14, 2014

Revised: June 1, 2015

Published: June 1, 2015 
(TCA) cycle, are transferred to the ETC and ultimately to $\mathrm{O}_{2}$. The energetically favorable movement of electrons within the ETC is coupled to the production of an electrochemical gradient across the inner membrane of the mitochondria, which is used to drive ATP synthesis. The critical role of oxygen in this process makes the ability to cope with changes in oxygen tension a metabolic priority. To maintain necessary energy levels under hypoxic stress, eukaryotic cells adapt by switching to anaerobic metabolism and substrate level phosphorylation. Most of the regulation necessary to make this metabolic switch is provided by HIF1 via transcriptional regulation of a battery of genes, including glycolytic enzymes, glucose transporters, and pyruvate dehydrogenase kinase. ${ }^{9}$ HIF 1 also impacts mitochondrial function via transcriptional regulation of $\mathrm{Bcl}-2$ /adenovirus E1B $19 \mathrm{kDa}$-interacting protein3 (Bnip3) expression. ${ }^{10,11}$ In addition, HIF1 negatively regulates mitochondrial biogenesis and $\mathrm{O}_{2}$ consumption by activating the transcription of genes that regulate c-Myc and by suppressing mitochondrial gene expression nontranscriptionally., ${ }^{9,2}$

The respiratory chain in the inner mitochondrial membrane contains four enzyme complexes (I-IV) through which electrons pass on their way to reducing $\mathrm{O}_{2}$ to water. Complex $\mathrm{I}$ is termed $\mathrm{NADH}$-ubiquinone oxidoreductase and reduces ubiquinone at the expense of $\mathrm{NADH}$, resulting in the net transfer of four protons across the inner membrane. Complex II, also known as succinate dehydrogenase, consists of only four peptides and is thus the simplest of all the complexes of the ETC. Complex II is also a TCA cycle enzyme and directly links the oxidation of succinate to fumarate with the reduction of ubiquinone to ubiquinol but does not translocate protons across the inner membrane. Complex III (also known as ubiquinone-cytochrome- $c$ oxidoreductase) enzymatically couples proton transfer to the oxidization of ubiquinol and the reduction of cytochrome $c$. Finally, complex IV, cytochrome $c$ oxidase $(\mathrm{CcO})$, completes the ETC by transferring the electrons from cytochrome $c$ to $\mathrm{O}_{2}$ and utilizing the exergonic oxygen reduction reaction to pump protons.

Mammalian $\mathrm{CcO}$ crystallizes as a dimer, with each monomer containing 13 subunits, where subunits $1-3$ are encoded by the mitochondrial genome. The other 10 subunits are nuclearencoded proteins with COX4, COX6A, COX6B, COX7A, and COX8 having tissue- and species-specific isoforms. ${ }^{13-16}$ COX4, specifically isoform 1 (Cox4i1), has been implicated in the allosteric inhibition of $\mathrm{CcO}$ via binding of ATP to the matrix domain. ${ }^{17,18}$ Hypoxia was shown to upregulate Cox4i2 isoform expression in liver and lung, which can alter $\mathrm{CcO}$ activity, ATP levels, and ROS production and is proposed as a mechanism for protecting tissues from oxidative damage. ${ }^{19,20}$ Cox6a isoforms are postulated to participate in mammalian thermogenesis by decreasing $\mathrm{H}^{+} / \mathrm{e}^{-}$ratios and increasing respiration and heat production. ${ }^{18}$ Cox7al is expressed tissue-specifically in heart and skeletal muscle, and Cox7a2, a liver-type isoform, is expressed ubiquitously. Though it has been suggested that Cox $7 a$ isoforms are associated with glucose uptake, total body aerobic capacity, StAR expression, and steroidogenesis, very little is known about the function of this isoform pair. ${ }^{21,22}$

To gain a more comprehensive understanding of the link between hypoxic stress, HIF $1 \alpha$ activation, and mitochondrial function, we generated two immortalized cell lines [Hifl $\alpha$, wild type (WT) and null] and measured extracellular oxygen levels (indicative of oxygen consumption rates) after exposure to mitochondrial modulators. Following challenge, the cells were also assessed for changes in mitochondrial function and the expression of genes that encode proteins that are important for ETC and OXPHOS via a comprehensive qPCR screen. The results revealed HIF $1 \alpha$-responsive genes within the ETC, especially in complex IV, subunit $7 \mathrm{al}$ of cytochrome $c$ oxidase (Cox7a1). Finally, the results suggest that $\mathrm{Hif} 1 \alpha$ plays a central role in regulating the specific activity of $\mathrm{CcO}$ under various experimental conditions. This most likely involves various mechanisms, such as allosteric regulation, the redox status of the cell, and, in cells that express both subunits, complex composition.

\section{EXPERIMENTAL PROCEDURES}

Mouse Embryonic Fibroblast (MEF) Isolation. $H$ if $1 \alpha^{\text {flox/flox }}$ transgenic mice were generous gifts from $\mathrm{R}$. Johnson (University of Cambridge, Cambridge, U.K.). Mice used in this study were kept at the animal housing facility under strict hygienic and pathogen-free conditions approved by the University Laboratory Animal Resource regulatory unit. All procedures were performed with the approval of the Michigan State University Committee on Animals Use and Care. Genotype-specific homozygous male and female mice were mated, and the females were kept isolated until day 14 of gestation (vaginal plug detection day was considered as day 0 ). Dams were anesthetized in a $\mathrm{CO}_{2}$ chamber for $90 \mathrm{~s}$ and then sacrificed using cervical dislocation. Embryos were surgically removed from the uterine horns and processed for fibroblast isolation using a protocol adapted from previous reports. ${ }^{23}$ Briefly, after surgical excision, embryos were transferred to a sterile cell culture hood, washed with $70 \%$ ethanol and PBS, cleaned (removal of liver, limbs, and head), diced, incubated with trypsin/EDTA at $37{ }^{\circ} \mathrm{C}$ for $30 \mathrm{~min}$, and then passed through a 22 gauge needle onto a $10 \mathrm{~cm}$ plate and placed in a $37{ }^{\circ} \mathrm{C}$ incubator.

Cell Culture. High-glucose (Glc) MEF medium was Dulbeco's modified Eagle's medium (DMEM) (cat 11965, Gibco, Grand Island, NY) containing glucose (4500 mg/L) supplemented with $10 \%$ heat-inactivated fetal bovine serum (FBS), 100 units $/ \mathrm{mL}$ penicillin, $100 \mu \mathrm{g} / \mathrm{mL}$ streptomycin, 2 $\mathrm{mM}$ L-glutamine, $0.1 \mathrm{mM}$ nonessential amino acids, and 10 $\mathrm{mM}$ HEPES ( $\mathrm{pH}$ 7.8). Galactose (Gal) MEF medium was glucose-free DMEM (cat 11966, Gibco) supplemented with 10 $\mathrm{mM}$ galactose and all additives described above. All cell culture work, unless otherwise specified, was performed under standard cell culture conditions $\left(5 \% \mathrm{CO}_{2}, 35 \%\right.$ humidity, and $\left.37{ }^{\circ} \mathrm{C}\right)$ in a NAPCO (Winchester, VA) model 7000 incubator for normoxic conditions $\left(21 \% \mathrm{O}_{2}\right)$ or in an $\mathrm{O}_{2}$-controlled glovebox (Coy Laboratory Products Inc., Grass Lake, MI) for hypoxic conditions $\left(1 \% \mathrm{O}_{2}\right)$.

MEF Cell Line Generation and Genotyping. Freshly isolated MEF cells were plated in $10 \mathrm{~cm}$ plates at $\sim 70 \%$ confluency with Glc medium changed daily. Cells were then immortalized by transfection with a plasmid construct (pRNS) containing the SV-40 large $\mathrm{T}$ antigen (a generous gift from C. C. Chang, Michigan State University) using Lipofectamine 2000 (Invitrogen, Carlsbad, CA) following the manufacturer's instructions. Positive stable integrants were selected with 300 $\mu \mathrm{g} / \mathrm{mL}$ G418 (Gibco). G418 resistant cells were split and infected with either LacZ recombinant (Ad-CMV-b-Gal) or Cre recombinase (Ad-CMV-Cre) adenovirus (Vector BioLabs, Philadelphia, PA) at 4000 multiplicity of infection for $48 \mathrm{~h}$. Cells were then plated at very low densities $(100$ cells $/ 15 \mathrm{~cm}$ plate), and when individual colonies became visible, clones were isolated and genotyped. Four WT and four null clones for 
Hif $1 \alpha$ were pooled in equal numbers to generate two cell lines, Hifl $\alpha$ WT and Hif $1 \alpha$ null. For genotyping, cell lines were grown to confluency in a $6 \mathrm{~cm}$ plate, rinsed and scraped with cold PBS $\left(4{ }^{\circ} \mathrm{C}\right)$, and collected by centrifugation. Genomic DNA extraction and genotyping were performed on the cell pellet as previously described (primer F, TTG GGG ATG AAA ACA TCT GC; primer R, GCA GTT AAG AGC ACT AGT TG). ${ }^{24}$ The size of the amplified gene for Hifl $\alpha$ WT was 962 bp.

Nuclear Protein Preparation. MEF cells were grown in 15 $\mathrm{cm}$ plates to confluency under normoxic $\left(21 \% \mathrm{O}_{2}\right)$ or hypoxic $\left(1 \% \mathrm{O}_{2}\right)$ conditions or with $150 \mu \mathrm{M} \mathrm{CoCl}$ for $24 \mathrm{~h}$, and protein extracts were prepared as described previously. ${ }^{3}$ Briefly, cells were washed with cold PBS $\left(4{ }^{\circ} \mathrm{C}\right)$ and removed from the plate surface by being scraped in cold $\left(4^{\circ} \mathrm{C}\right)$ PBS and collected by centrifugation. Nuclear fractions were prepared by lysing the cells in $10 \mathrm{mM}$ Tris ( $\mathrm{pH} 7.5$ ), $1.5 \mathrm{mM} \mathrm{MgCl}_{2}, 10 \mathrm{mM} \mathrm{KCl}$ supplemented with Complete-mini EDTA-free protease inhibitor tablets (Roche Applied Science, Indianapolis, IN), 2 mM DTT, $1 \mathrm{mM} \mathrm{Na} \mathrm{VO}_{4}$, and $0.4 \mathrm{mM}$ PMSF and kept on ice for $10 \mathrm{~min}$. Nuclei were collected by centrifugation $(12000 \mathrm{~g}$ for

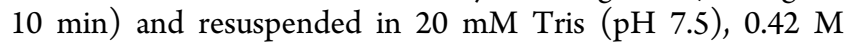
$\mathrm{KCl}, 20 \%$ glycerol, and $1.5 \mathrm{mM} \mathrm{MgCl}_{2}$ supplemented as described above and rotated for $45 \mathrm{~min}$ at $4{ }^{\circ} \mathrm{C}$. Insoluble material was removed by centrifugation $(20000 \mathrm{~g}$ for $10 \mathrm{~min}$ ), and the protein concentrations of the supernatant were determined using the Bio-Rad (Hercules, CA) Bradford assay kit and BSA standards. ${ }^{25}$ Protein samples were analyzed for HIF1 $\alpha$ stabilization through Western blotting.

Mitochondrial Protein Preparation. MEF cells were grown in $15 \mathrm{~cm}$ plates to confluency under normoxic $\left(21 \% \mathrm{O}_{2}\right)$ or hypoxic $\left(1 \% \mathrm{O}_{2}\right)$ conditions for $24 \mathrm{~h}$, and mitochondria were isolated using a protocol adapted from a previous report. ${ }^{26}$ Briefly, cells were washed with cold PBS $\left(4{ }^{\circ} \mathrm{C}\right)$ and removed from the plate surface by being scraped in solution $\mathrm{A}(0.25 \mathrm{M}$ sucrose, $20 \mathrm{mM}$ HEPES, $10 \mathrm{mM} \mathrm{KCl}, 1.5 \mathrm{mM} \mathrm{MgCl}, 1 \mathrm{mM}$ EDTA, $1 \mathrm{mM}$ EGTA, $1 \mathrm{mM}$ DTT, and $0.1 \mathrm{mM}$ PMSF). Samples were then subjected to three freeze/thaw cycles with mixing by pipet for each thaw, and insoluble material was removed by centrifugation ( $700 \mathrm{~g}$ for $10 \mathrm{~min}$ at $4{ }^{\circ} \mathrm{C}$ ). The supernatant was further cleared by centrifugation $(10000 \mathrm{~g}$ for $15 \mathrm{~min}$ at $4{ }^{\circ} \mathrm{C}$ ) and aspirated, and the pellet was resuspended in solution A. Mitochondrial protein concentrations were determined using the Bio-Rad Bradford assay kit and BSA standards. ${ }^{25}$ Protein samples were analyzed for $\mathrm{C} c \mathrm{O}$ enzyme activity.

Western Blotting. Protein samples were separated by sodium dodecyl sulfate-polyacrylamide gel electrophoresis (SDS-PAGE) and transferred to a nitrocellulose membrane. Western blots were performed with rabbit antibodies against HIF1 $\alpha$ (NB100-479, Novus Biologicals, Inc., Littleton, CO) and $\beta$-actin (SC-7210, Santa Cruz Biotechnology, Inc., Dallas, TX). Proteins were visualized with horseradish peroxidaseconjugated goat anti-rabbit IgG (sc-2004, Santa Cruz Biotechnology, Inc.) and an ECL Western blot system (Pierce, Rockford, IL).

Oxygen Consumption Rate (OCR) Measurements. OCR was measured using an XF24 Extracellular Flux Analyzer (Seahorse Bioscience, Billerica, MA) as described in the manufacturer's instructions. Hif $1 \alpha$ WT and null cells, preadapted to medium glucose levels for $24 \mathrm{~h}$, were plated in Glc or Gal medium at a density of 40000 cells/well and were allowed to adhere to the plate for $24 \mathrm{~h}$. The culture medium was then replaced with specific XF24 assay medium. Glc XF24 assay medium consisted of DMEM base (cat D5030, SigmaAldrich, St. Louis, MO) supplemented with $25 \mathrm{mM}$ glucose, 31 $\mathrm{mM} \mathrm{NaCl}, 1 \mathrm{mM}$ sodium pyruvate (Atlanta Biologicals, Inc., Flowery Branch, GA), 2 mM GlutaMAX (Gibco), and $15 \mathrm{mg} / \mathrm{L}$ phenol red (Sigma-Aldrich). Gal XF24 assay medium consisted of DMEM base (cat D5030, Sigma-Aldrich) supplemented with $10 \mathrm{mM}$ galactose instead of glucose and all additives described above. Measurement of OCR was started $90 \mathrm{~min}$ after switching XF24 assay medium, and the inhibitors of ETC and OXPHOS system were injected in the following order: oligomycin A $(1 \mu \mathrm{M})$, CCCP $(1.5 \mu \mathrm{M}$ for WT and $0.75 \mu \mathrm{M}$ for null cells), and rotenone $(0.5 \mu \mathrm{M}) /$ antimycin $\mathrm{A}(0.5 \mu \mathrm{M})$. The concentration of CCCP for each cell line was optimized by measuring OCR in different nutrient environments, Glc or Gal XF24 assay medium. After OCR had been measured, cells were washed with cold PBS and lysed in buffer $[10 \mathrm{mM}$ Tris- $\mathrm{HCl}$ $(\mathrm{pH} 7.5)$ and $0.1 \%$ Triton $\mathrm{X}-100$ ] by being frozen and thawed. The total protein amounts in each well were determined using a Bio-Rad Bradford assay kit and BSA standards. ${ }^{25}$ The OCR (picomoles per minute) was divided by total protein amounts for each well, and spare respiratory capacity was calculated by manufacturer's software, the XF Mito Stress Test Report Generator.

RNA Isolation and Quantitative Real-Time PCR (qPCR). RNA was isolated from the two different cell strains cultured in different carbon sources and at different oxygen tensions using TRIzol reagent via the manufacturer's instructions (Invitrogen). RNA pellets were resuspended in $\mathrm{ddH}_{2} \mathrm{O}$ and quantified spectrophotometrically $(260 \mathrm{~nm})$. Total RNA $(2 \mu \mathrm{g})$ was reverse transcribed by SuperScript III using an anchored oligo- $(\mathrm{dT})_{20}$ primer as described by the manufacturer (Invitrogen). The resulting cDNA was diluted in $\mathrm{ddH}_{2} \mathrm{O}$ and used as a template for high-throughput qPCR (HTP qPCR) and manual qPCR. Primer pairs were designed to amplify 104 nuclear genes that encode specific mitochondrially related proteins (Table S1 of the Supporting Information). In total, 40 ETC complex I, 4 ETC complex II, 16 ETC complex III, 15 ETC complex IV, and 19 ETC complex V genes were assayed. Five uncoupling proteins, three chaperone, three housekeeping reference, and five control genes (one stress-responsive gene and four HIF $1 \alpha$-responsive genes) were also examined.

HTP qPCR mixtures consisting of $2 \mu \mathrm{L}$ of $\mathrm{cDNA}$, each primer at $0.3 \mu \mathrm{M}$, and $2 \times$ Power SYBR Green PCR Master Mix (Applied Biosystems, Foster City, CA) were aliquoted into 384well plates using a Biomeck 2000 Laboratory Automation Workstation (Beckman Coulter Inc., Fullerton, CA). Amplification was conducted using an Applied Biosystems PRISM $7900 \mathrm{HT}$ Sequence Detection System. Quantification was determined using the comparative $C_{\mathrm{T}}$ method $\left(\Delta \Delta C_{\mathrm{T}}\right)$ (Applied Biosystems). The geometric mean of the expression of three housekeeping genes (Actb, Hprt, and Ppia) was used to control for differences in RNA loading, quality, and cDNA synthesis. Fold changes in expression were calculated with HTP qPCR results using the $\Delta \Delta C_{\mathrm{T}}$ method with the WT Glc control (WT Glc Ctrl) group for each time point (4 and $24 \mathrm{~h}$ ) being scaled to equal 1 . Cluster version 3.0 was used to generate average linkage files, and Maple Tree version 0.2.3.2 BETA (http://sourceforge.net/projects/mapletree/) was used to create colored dendrograms from the linkage files, where red indicates upregulation and green indicates downregulation. ${ }^{27}$

Manual qPCR was performed with $25 \mu \mathrm{L}$ reactions $(5 \mu \mathrm{L}$ of cDNA template, each primer at $0.3 \mu \mathrm{M}, 3 \mathrm{mM} \mathrm{MgCl}_{2}, 200 \mu \mathrm{M}$ 
dNTPs, 0.6 unit of AmpliTaq Gold, and 10× SYBR Green PCR Buffer) and amplified using an Applied Biosystems PRISM 7000 Sequence Detection System. The Hprt housekeeping gene was a reference, and expression levels of key genes (Slc2a1, Vegfa, Cox4i1, Cox4i2, Bnip3, Cox6a1, Cox6a2, Cox7a1, and Cox7a2) were calculated using the $\Delta \Delta C_{\mathrm{T}}$ method. Fold changes of Slc2a1, Vegfa, and Bnip3 were calculated compared to the WT Glc control group (WT Glc Ctrl) for $24 \mathrm{~h}$ being scaled to equal 1. Fold changes of Cox4i1, Cox4i2, Cox6a1, Cox6a2, Cox7a1, and Cox7a2 were expressed compared to the WT Glc Ctrl of one isoform of each Cox subunit for $24 \mathrm{~h}$ being scaled to equal 1 .

Measurement of $\mathrm{CcO}$ Enzyme Activity. $\mathrm{CcO}$ activity was determined as previously described with slight modifications. ${ }^{28}$ Bovine heart cytochrome $c$ was dissolved in assay buffer (40 $\mathrm{mM}$ phosphate buffer and $0.5 \%$ Tween 80 ) at $0.4 \mathrm{mg} / \mathrm{mL}$ and was reduced using sodium dithionite. The fully reduced cytochrome $c$ was confirmed by the ratio of absorbance at 550 and $565 \mathrm{~nm}$, and the change in absorbance at $550 \mathrm{~nm}$ was recorded as a function of time for the $\mathrm{CcO}$ assay. After the absorbance at $550 \mathrm{~nm}$ of reduced cytochrome $c\left(A_{\text {red }}\right)$ had been recorded, isolated mitochondria were added and the absorbance at $550 \mathrm{~nm}$ was recorded every $5 \mathrm{~s}$ for $3 \mathrm{~min}$. The initial $\mathrm{CcO}$ activity was calculated using the expression

$$
\begin{aligned}
& \left(\Delta \mathrm{Abs}_{550} / \mathrm{min}\right) \times(\text { total assay volume }) \\
& /\left[19.6 \mathrm{mM}^{-1} \times(\text { mitochondrial volume })\right. \\
& \quad \times(\text { mitochondrial concentration })]
\end{aligned}
$$

with units of micromoles per minute per milligram. The specific activity was calculated as a turnover number in inverse minutes, dividing $\mathrm{CcO}$ activity in micromoles per minute per milligram protein by mitochondrial $\mathrm{CcO}$ concentration in micromoles per milligram protein. The absorbance for $\mathrm{CcO}$ activity was measured using a SpectraMax M2 spectrophotometer (Molecular Devices, Sunnyvale, CA).

Mitochondrial CCO Measurement. The concentration of cytochrome $a a_{3}(\mathrm{CcO})$ was determined as previously described $^{29}$ by measuring the visible difference spectra (dithionite-reduced minus ferricyanide-oxidized) of the detergent-solubilized mitochondria from 500 to $700 \mathrm{~nm}$. The peak at $605 \mathrm{~nm}$ represented the reduced minus oxidized peak of cytochrome $a$. The concentration of $\mathrm{CcO}$ was calculated using the extinction coefficient for reduced-oxidized $\mathrm{CcO}$ of 24 $\mathrm{mM}^{-1} \mathrm{~cm}^{-1}$ at $605-630 \mathrm{~nm}$.

Statistical Analysis. The result of spare respiratory capacity was analyzed for significant differences by analysis of variance (ANOVA) followed by Tukey's post hoc test.

\section{RESULTS}

Creation of Hif1 $\alpha$ WT and Null Cells. The genotype of the Hif $1 \alpha \mathrm{WT}$ and Hifl $\alpha$ null cells was confirmed by PCR, and the extent of recombination was approximately $100 \%$ in the nulls (Figure 1A). To confirm the functional deletion of the Hif $1 \alpha$ gene, HIF $1 \alpha$ protein levels following exposure to control conditions (Ctrl), $150 \mu \mathrm{M} \mathrm{CoCl}_{2}(\mathrm{Co})$, or hypoxia $\left(1 \% \mathrm{O}_{2}\right.$, Hyp) for $24 \mathrm{~h}$ were examined by Western blot analysis (Figure 1B). Hifl $\alpha$ null cells did not express HIF $1 \alpha$ protein under $\mathrm{CoCl}_{2}$ or hypoxia, confirming that recombination-induced functional deletion of Hifl $\alpha$ gene was approximately $100 \%$.

Cellular Respiration in Hif1 $\alpha$ WT and Null Cells under Different Energy Sources. To determine the role of HIF1 $\alpha$

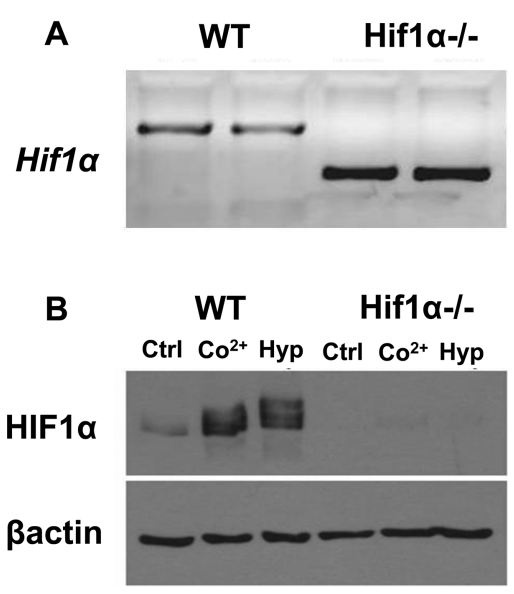

Figure 1. Genotype and protein comparisons of Hifl $\alpha$ WT and null cells. (A) Hifl $\alpha$ WT and null cells were harvested; DNA was extracted, and PCR-based genotyping was performed using Hifl $\alpha$ primers described in Experimental Procedures. (B) Hifl $\alpha$ WT and null cells were exposed to control conditions (Ctrl), $150 \mu \mathrm{M} \mathrm{CoCl}_{2}\left(\mathrm{Co}^{2+}\right)$, or $1 \% \mathrm{O}_{2}$ ( $\mathrm{Hyp}$ ) for $24 \mathrm{~h}$. Nuclear protein was extracted and separated by SDS-PAGE, transferred to a nitrocellulose membrane, and probed with a HIF $1 \alpha$-specific (top) or $\beta$-actin-specific (bottom) antibody ( $n=$ 2).

in cellular respiration, the extracellular oxygen flux of each cell line in different nutrients was measured to calculate OCR (Figure 2). OCR was monitored in the presence of ETC and OXPHOS inhibitors, oligomycin (a), CCCP (b), and rotenone/antimycin (c), in Hif1 $\alpha$ WT and null cells in Glc and Gal media (Figure 2A). It is important to note that spare respiratory capacity was described as maximal respiration [i.e., the OCR in the presence of CCCP (44.9 $\mathrm{min}$ in Figure 2A)] divided by a basal respiration (OCR at $9.9 \mathrm{~min}$ in Figure $2 \mathrm{~A}$ ) times 100 (Figure 2B). The Hif1 $\alpha$ WT cells in both Glc and Gal media had spare respiratory capacities significantly higher than those of Hif $1 \alpha$ null cells in the Gal media (WT Glc, 182\%; WT Gal, 222\%; null Gal, 100\%). The Hifl $\alpha$ null cells in the Glc media showed a spare respiratory capacity of $158 \%$, but this was not significant when compared to that of null cells in the Gal media. Similar results were also observed in the two cell types and under different conditions when pericellular oxygen consumption was measured using a SensorDish Reader (PreSens Precision Sensing GmbH, Regensburg, Germany) ${ }^{30}$ (data not shown).

Screening HIF1-Dependent mRNA Expression of Nuclear-Encoded Mitochondrial Genes. The oxygen consumption data suggest that the cellular respiration efficiency in the two cell types is inherently different. To further elucidate the role of HIF $1 \alpha$ in mitochondrial function, HTP qPCR was utilized to screen the expression levels of 104 nuclear-encoded genes associated with the ETC and mitochondrial function. Hif1 $\alpha$ WT and null cells were exposed to control (Ctrl) conditions or $1 \% \mathrm{O}_{2}$ (Hyp) in both Glc and Gal media for 4 and $24 \mathrm{~h}$ (Figure $3 \mathrm{~A}$ ). Compared to the $24 \mathrm{~h}$ time point, the 4 $\mathrm{h}$ time point showed a high percentage of downregulated genes. Five groupings of differentially expressed genes are indicated in Figure 3A. Group 1 has many genes that were upregulated at 4 $\mathrm{h}$ and downregulated at $24 \mathrm{~h}$, including the complex I genes $N d u f c 2, N d u f s 4$, and $N d u f b 3$. Group 2 contains the positive control HIF $1 \alpha$-regulated genes (Bnip3, Slc2a1, and Vegfa) along with Cyb5r2, Cox6a2, and Cox7a1, which, in particular, show a classic HIF1 $\alpha$-regulated expression pattern (Figure3B). 
A
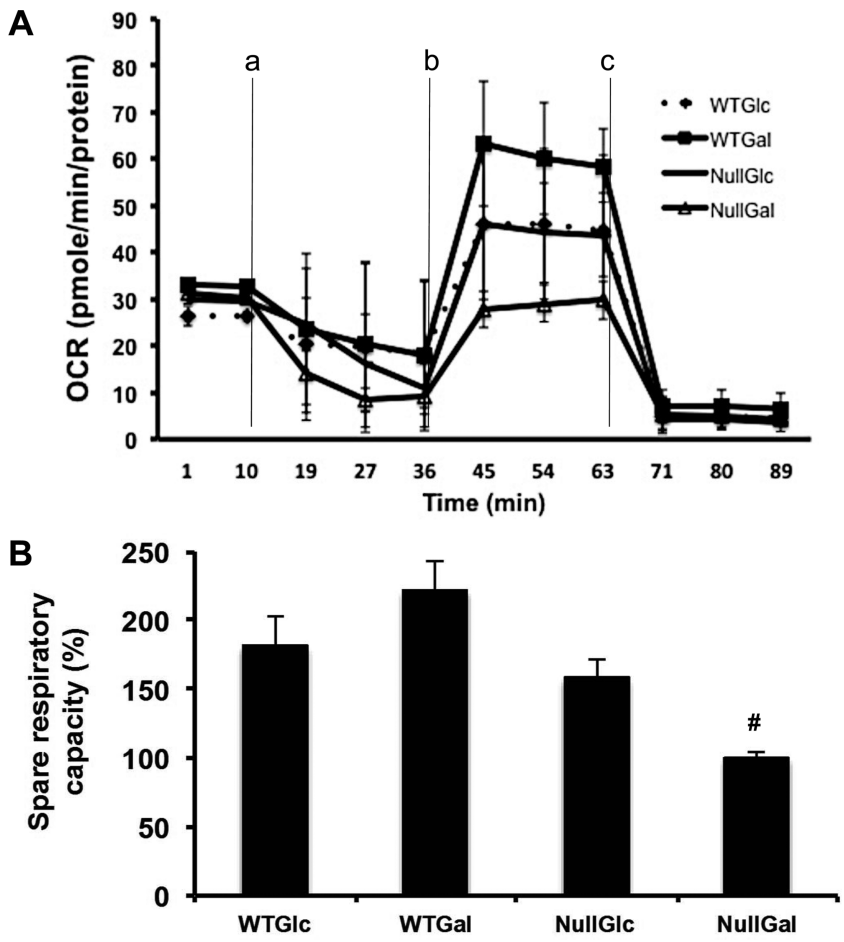

Figure 2. Measurement of oxygen consumption rate (OCR) from Hif1 $\alpha$ WT and null cells. (A) OCR, calculated as picomoles per minute per protein amount in the XF24 assay medium of Hif1 $\alpha$ WT and null cells grown in Glc or Gal media, measured after exposure to (a) oligomycin $(1 \mu \mathrm{M})$, (b) CCCP $(1.5 \mu \mathrm{M}$ for WT and $0.75 \mu \mathrm{M}$ for null cells), and (c) rotenone $(0.5 \mu \mathrm{M}) /$ antimycin A $(0.5 \mu \mathrm{M})$. Lines indicate average values \pm standard errors $(n=3)$. (B) Spare respiratory capacity as a percentage calculated with maximal respiration (OCR at $44.9 \mathrm{~min}$ ) and basal respiration (OCR at 9.9 $\mathrm{min}$ ) by the manufacturer's software, the XF Mito Stress Test Report Generator. Data were analyzed for significant differences by ANOVA followed by Tukey's post hoc test. A number sign indicates significant differences at $p<0.05$.

Most of the group 3 genes were downregulated at $4 \mathrm{~h}$ and upregulated at $24 \mathrm{~h}$ without showing a distinct HIF $1 \alpha$-regulated expression pattern, such as Lonp1, Cox4i2, and Cyb5r1. There was a small group of genes (group 4) that showed greater upregulation in the null than in the WT cell line at both 4 and $24 \mathrm{~h}$ time points. This group includes the mitochondrial uncoupling protein (UCP4) gene, Slc25a27, and ATP synthase subunits Atp $5 j 2$ and Atp $5 c 1$. Finally, group 5 is primarily composed of genes whose expression was downregulated at both 4 and $24 \mathrm{~h}$ regardless of cell type, in particular the ETC complex II genes Sdha, Sdhc, and Sdhd.

HIF1-Dependent Gene Expression of Nuclear-Encoded Mitochondrial CcO Genes. Manual qPCR was performed on select genes that were dependent upon HIF $1 \alpha$ mediated regulation in HTP qPCR. Classic HIF $1 \alpha$-regulated genes Slc2a1, Vegfa, and Bnip3 showed the expected higher level of expression in the Hifl $\alpha$ WT cells in response to a $24 \mathrm{~h}$ hypoxia treatment compared to control and Hifl $\alpha$ null cells (Figure 4A). Several genes associated with $\mathrm{CcO}$ showed differential patterns of gene expression among the different isoforms (Figure 4B-D). Cox4il had a higher level of expression when cells were exposed to Gal media and hypoxia. Cox4i2 had a higher level of expression in Hifl $\alpha$ null cells under hypoxia than in WT cells regardless of sugar sources. The level of Cox6a1 expression was higher in Hifl $\alpha$ null cells regardless
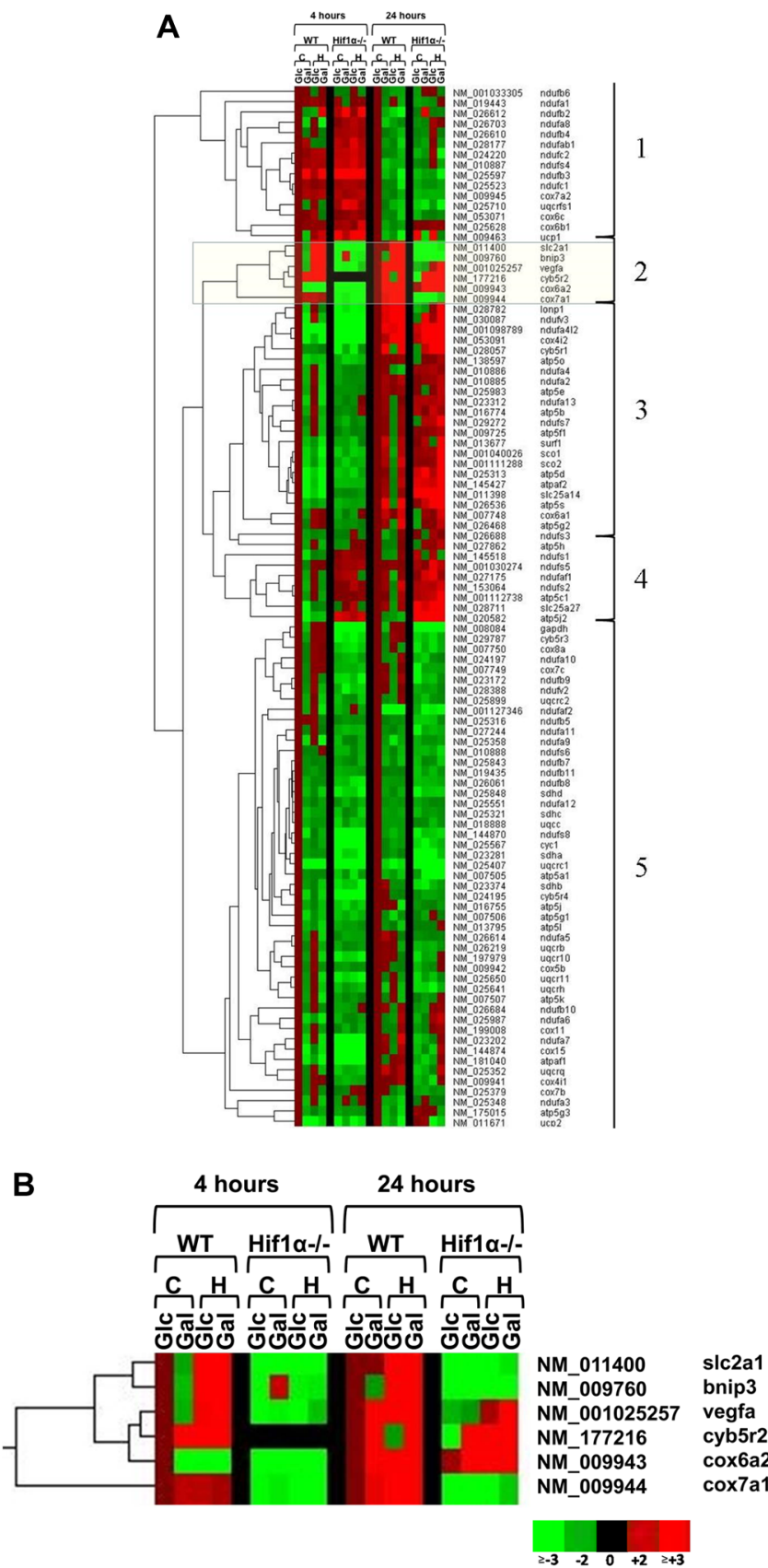

Figure 3. Dendrograms. Gene expression fold changes calculated with HTP qPCR results using the $\Delta \Delta C_{\mathrm{T}}$ method for Hifl $\alpha$ WT and null cells exposed to control conditions $(\mathrm{C})$ and $1 \% \mathrm{O}_{2}(\mathrm{H})$ in highglucose media (Glc) or galactose media (Gal) at 4 and $24 \mathrm{~h}$. The cell and medium control group (e.g., WT Glc) at each time point was scaled to 1 . Red indicates upregulation, green downregulation, and black no data. (A) Genes are separated into five groups based on clustering and expression profiles. (B) Group 2 contains known HIF $1 \alpha$-regulated genes Slc2al, Bnip3, and Vegfa.

of nutrient type, while the level of Cox6a2 expression was higher in Gal media regardless of cell type (WT and null cells). In agreement with Figure 3, Cox7al displayed a classic HIF1 $\alpha$ dependent expression pattern, being upregulated by hypoxia in the Hif $1 \alpha$ WT, especially an increase in Glc media, but not the Hif $1 \alpha$ null cells. Cox7a2 expression did not change between cell types or in response to treatments. 



Figure 4. Gene expression of control and select mitochondrial genes. Known HIF $1 \alpha$ target genes (A) and selected $\mathrm{CcO}$ subunit genes (B-D) were assessed by manual qPCR of Hifl $\alpha$ WT and null cells after exposure to treatment for $24 \mathrm{~h}$. Treatment designations include high-glucose media $(\mathrm{Glc})$, galactose media $(\mathrm{Gal})$, control conditions $(\mathrm{Ctrl})$, and $1 \% \mathrm{O}_{2}(\mathrm{Hyp})$. The $y$-axis indicates the fold change that was calculated using $2^{\left(-\Delta \Delta C_{\mathrm{T}}\right)}$. (A) The fold change for Slc2a1, Bnip3, and Vegfa was a comparison to the fold of WT Glc Ctrl being scaled to 1 within each gene. (B) Fold change of Cox4 was a comparison to the fold of WT Glc Ctrl of Cox4il scaled to 1. (C) The fold change of Cox6 was a comparison to the fold of WT Glc Ctrl of Cox6a1 scaled to 1. (D) The fold change of Cox7 was a comparison to the fold of WT Glc Ctrl of Cox7a1 scaled to 1. Bars indicate average values \pm standard errors of the mean except the gene expression of Slc2a1 ( $n=3$ for Vegfa, Cox4il, and Cox4i2; $n=4$ for Bnip3, Cox6a1, and Cox6a2; $n=5$ for Cox7a2; $n=7$ for Cox7a1). Bars for Slc2a1 expression indicate average values \pm the standard deviation $(n=1)$.

Table 1. CcO Enzyme Activity

\begin{tabular}{|c|c|c|c|c|c|c|c|}
\hline \multirow[b]{2}{*}{ nutrient } & \multirow[b]{2}{*}{ MEF } & \multirow[b]{2}{*}{ oxygen } & $\mathrm{CcO}$ activity & \multicolumn{3}{|c|}{$\mathrm{CcO}$ protein concentration } & \multirow[b]{2}{*}{$\begin{array}{l}\text { specific activity } \\
\left(\mathrm{s}^{-1}\right)\end{array}$} \\
\hline & & & $\begin{array}{c}\text { oxidation of cytochrome } c\left[\mu \mathrm{mol} \mathrm{min}^{-1} \text { (mg of }\right. \\
\left.\text { protein })^{-1}\right]\end{array}$ & $\begin{array}{l}{[\mathrm{CcO}]} \\
(\mathrm{mM})\end{array}$ & $\begin{array}{l}{[\mathrm{protein}]} \\
(\mathrm{mg} / \mathrm{mL})\end{array}$ & $\begin{array}{c}{[\mathrm{CcO}]} \\
(\mu \mathrm{mol} / \mathrm{mg})\end{array}$ & \\
\hline \multirow[t]{4}{*}{ glucose } & \multirow[t]{2}{*}{ WT } & Ctrl & 0.0435 & $2.7 \times 10^{-4}$ & 5.7 & $4.71 \times 10^{-5}$ & 15.4 \\
\hline & & Hyp & 0.0320 & $3.7 \times 10^{-4}$ & 6.0 & $6.11 \times 10^{-5}$ & 8.7 \\
\hline & \multirow[t]{2}{*}{ Hif $1 \alpha-/-$} & Ctrl & 0.0409 & $3.1 \times 10^{-4}$ & 5.6 & $5.55 \times 10^{-5}$ & 12.3 \\
\hline & & Hyp & 0.0391 & $2.5 \times 10^{-4}$ & 5.2 & $4.80 \times 10^{-5}$ & 13.6 \\
\hline \multirow[t]{4}{*}{ galactose } & \multirow[t]{2}{*}{ WT } & Ctrl & 0.0476 & $2.1 \times 10^{-4}$ & 4.7 & $4.54 \times 10^{-5}$ & 17.5 \\
\hline & & Hyp & 0.0520 & $1.7 \times 10^{-4}$ & 3.6 & $4.67 \times 10^{-5}$ & 18.5 \\
\hline & \multirow[t]{2}{*}{ Hif $1 \alpha-/-$} & Ctrl & 0.0418 & $2.4 \times 10^{-4}$ & 4.4 & $5.49 \times 10^{-5}$ & 12.7 \\
\hline & & Hyp & 0.0944 & $9.1 \times 10^{-5}$ & 2.5 & $3.68 \times 10^{-5}$ & 42.7 \\
\hline
\end{tabular}

HIF1 $\alpha$-Dependent Regulation of CcO Activity. The results of transcriptional $\mathrm{CcO}$ subunit expressions suggest that HIF $1 \alpha$ plays a role in modulating the expression of Cox7a1 and, potentially, other critical subunits. A biochemical assessment of the $\mathrm{CcO}$ activity was performed to determine if its activity was influenced by changes in Hifl $\alpha$ genotype. Hif $1 \alpha$ WT and null cell lines were exposed to control conditions and $1 \% \mathrm{O}_{2}$ for $24 \mathrm{~h}$ in both Glc and Gal media, and mitochondria were isolated. $\mathrm{CcO}$ activity and quantity were assessed in these isolated mitochondria (Table 1). The specific activity of $\mathrm{CcO}$ remained fairly constant in both cell strains and different treatment paradigms, with two exceptions. The WT cells showed a decrease in $\mathrm{CcO}$ activity following hypoxic exposure in Glc-containing media that was not evident in Gal-containing media. In addition, the null cells grown in Gal media showed an almost 3-fold increase in $\mathrm{CcO}$ specific activity under hypoxic stress. This increase reflects both an increase in enzyme activity and a decrease in enzyme concentration under these conditions. These data suggest that loss of HIF $1 \alpha$ signaling removes the cell's ability to regulate $\mathrm{CcO}$ activity under hypoxic stress and that maintenance of this activity below a given threshold is important for mitochondrial viability. However, the observed changes in $\mathrm{CcO}$ activity under some conditions may not be explained by changes in $\mathrm{CcO}$ isoform composition 

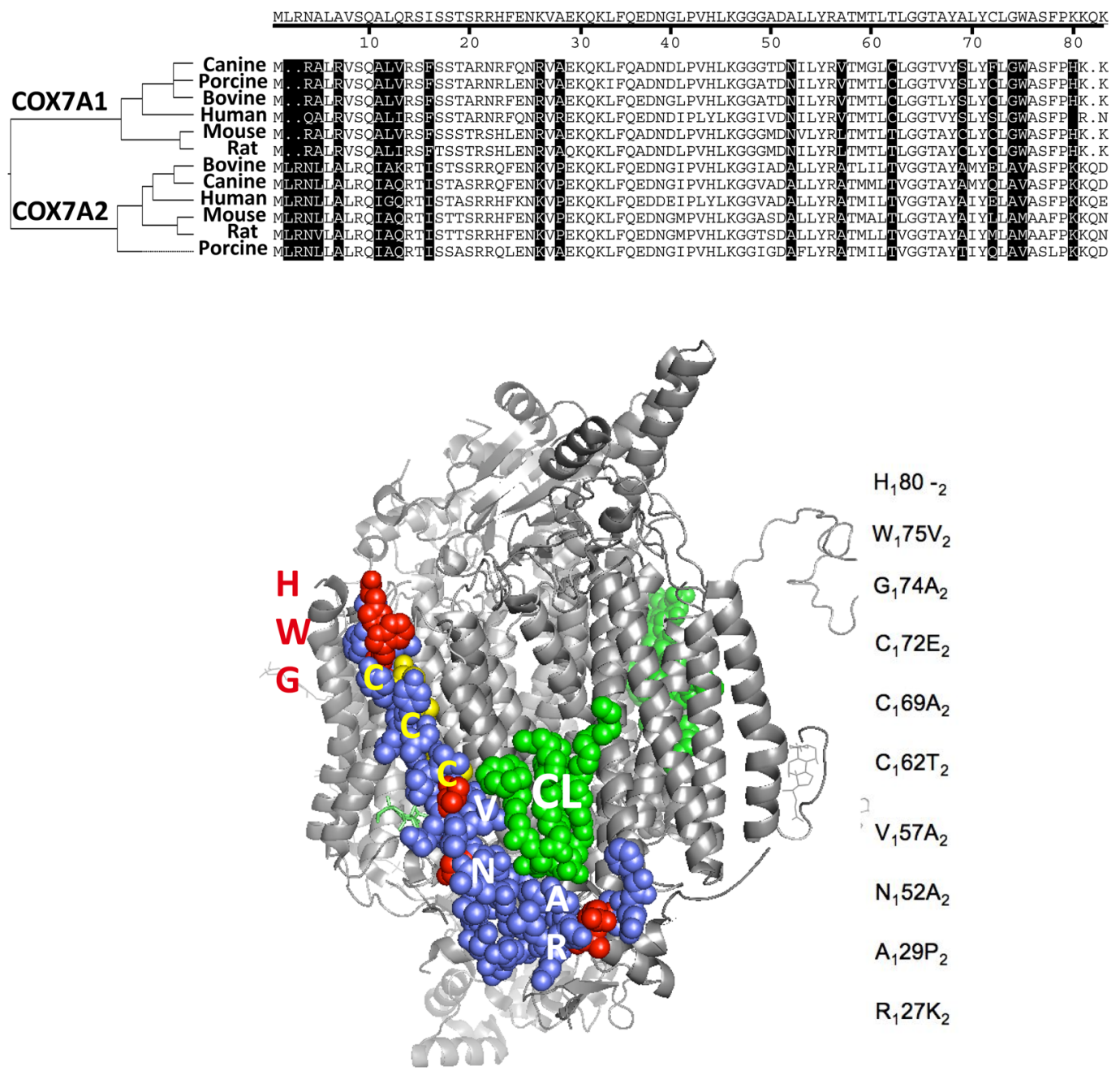

Figure 5. Comparative amino acid sequences for COX7A1 and COX7A2 isoforms and a $3 \mathrm{D}$ representation of the $\mathrm{CcO}$ monomer. The residues that are altered between 7A1 and 7A2 are listed to the right of the model, with subscripts indicating the isoform and their locations highlighted in red or yellow in the structure. The whole $\mathrm{CcO}$ structure is in grey and COX7A1 in purple. A molecule of cardiolipin, $\mathrm{CL}$, is shown in green. The top of the figure is the intermembrane side, the bottom is the matrix side. The COX7A1 structure is not completely resolved in the bovine crystal structure: it starts at phenylalanine 24 on the bottom ( $\mathrm{N}$-terminal, matrix side). The figure was made in PyMOL from the coordinates of bovine cytochrome $c$ oxidase PDB 2dyr.

because Cox7al transcripts constitute $<1 \%$ of total subunit 7 a transcripts in our cell lines (Figure 4D) even after hypoxic induction (see Discussion).

COX7A Subunit and $\mathrm{CcO}$ Protein Structure. The hypoxia-induced expression of Cox7al appears to be HIF $1 \alpha$ dependent, and loss of HIF $1 \alpha$ signaling affects the capacity of mitochondria to regulate oxygen consumption and $\mathrm{CcO}$ specific activity following hypoxic stress. In cells that express significant amounts of both isoforms, HIF $1 \alpha$ might alter the subunit composition of $\mathrm{C} c \mathrm{O}$ upon hypoxia exposure to maintain $\mathrm{CcO}$ activity within acceptable limits to sustain mitochondrial viability. To begin to gain a mechanistic understanding of this role, protein sequence alignment and structural visualization were performed. COX7A1 and COX7A2 are highly conserved across multiple species (e.g., human, 59.7\% identical and $79.1 \%$ similar; mouse, $58.4 \%$ identical and $72.7 \%$ similar). The structure of bovine $\mathrm{CcO}$, a 13 -subunit enzyme that is highly homologous to that of the mouse, shows the location of the Lshaped COX7A subunit in blue and an associated cardiolipin molecule in green (Figure 5). This membrane-embedded face of $\mathrm{CcO}$ is an area that appears to interact with complex III (cytochrome $b c_{1}$ ) when they associate with complex I to form a supercomplex. ${ }^{31}$ Part of the interaction appears to be mediated by cardiolipin and COX7A, and thus, the sequence variation between the 7A1 and 7A2 isoforms might well be expected to influence this interaction. The region of most sequence divergence is the $\mathrm{N}$-terminus, at the bottom of the $\mathrm{L}$ and not completely resolved in the crystal structure. In addition, the protein sequences show distinct differences at specific residues along the surface of the helix comprising most of the subunit (i.e., $\mathrm{R}_{1} 27 \mathrm{~K}_{2}, \mathrm{~A}_{1} 29 \mathrm{P}_{2}, \mathrm{~N}_{1} 52 \mathrm{~A}_{2}, \mathrm{~V}_{1} 57 \mathrm{~A}_{2}, \mathrm{C}_{1} 62 \mathrm{~T}_{2}, \mathrm{C}_{1} 69 \mathrm{~A}_{2}$, and $\mathrm{C}_{1} 72 \mathrm{E}_{2}$ ). COX4, COX6A, COX7A, and COX8 are also rendered, and these subunits impact the conformation for interaction with cytochrome $b c 1$ (not shown). Given these sequence differences and hypoxic-responsive gene COX4 localization at the same side with COX7A, switching COX7A subunits under hypoxic stress might allow $\mathrm{CcO}$ to alter its interactions with other ETC complexes during the formation of supercomplexes. ${ }^{32,33}$ In addition, because a number of these residues are cysteines, the switch from COX7A2 to COX7A1 might render the $\mathrm{CcO}$ more redox sensitive or serve to protect it from oxidative damage while under hypoxic stress. ${ }^{16,34}$ 


\section{DISCUSSION}

In this study, we demonstrate a role of $\operatorname{HIF} 1 \alpha$ in the basal oxygen utilization rate and the ETC function of MEF cells and establish HIF1 $\alpha$ regulation of genes associated with cytochrome $c$ oxidase $(\mathrm{CcO})$. Gene expression changes for $\mathrm{CcO}$ components occur in response to hypoxia, and the extracellular oxygen concentrations (oxygen consumption rate data) support an apparent constitutive modulation of mitochondrial function by HIF $1 \alpha$. This study adds to the growing body of evidence that the hypoxia signaling system (especially HIF $1 \alpha$ ) regulates ETC biogenesis and processes associated with mitochondrial function, such as energy production, reactive oxygen species homeostasis, autophagy/apoptosis, and oxygen consumption.

Addition of exogenous glucose to cultured cells will increase the rate of glycolysis and inhibit OXPHOS, a phenomenon known as the Crabtree effect. ${ }^{35}$ A change from Glc to Gal in culture media increases the respiration rate and cytosolic $\mathrm{pH}$, increases the rate of cellular oxygen consumption, and results in mitochondrial remodeling. ${ }^{35,36}$ In human primary myotubes, Gal medium enhances aerobic metabolism and decreases the rate of anaerobic glycolysis. ${ }^{37}$ Our results support these observations with an increased spare respiratory capacity in the Hif1 $\alpha$ WT cells (Figure 2B) and dramatic changes in ETC gene expression profiles in response to Gal (Figure 3). ${ }^{38-40}$ For example, after $24 \mathrm{~h}$, expression profiles show genes upregulated in response to Gal only in the presence of HIF1 $\alpha$ (e.g., Ndufa10), in the absence of HIF $1 \alpha$ (e.g., Atp5l), and regardless of HIF $1 \alpha$ status (e.g., Surf1). Cox $8 a$ showed upregulation in response to glucose only when $\operatorname{HIF} 1 \alpha$ was present, while $U_{c p} 1$ conversely showed upregulation only in Hifl $\alpha$ null cells. Rossignol et al. found no greater levels of mitochondria in $\mathrm{HeLa}$ cells grown with galactose than those grown with glucose; however, there were significant galactose-induced changes in mitochondrial protein expression in both HeLa and MRC5 fibroblast cells. ${ }^{36}$ MRC5 fibroblast cells had significantly increased protein quantities for complex I, II, and IV subunits, while complex III protein levels were not increased. In our $24 \mathrm{~h}$ study, the complex III genes were almost all downregulated in the HIF $1 \alpha$ null cells with mixed responses in regard to Gal (e.g., Uqcrcl, Uqcrh, and Uqcrq). The uniqueness of the complex III response to Gal is a point of interest as the role of ROS generated at complex III has been implicated in HIF stabilization and signaling, though this is debated. ${ }^{8,41,42}$ Clearly, there is a complex interaction between HIF $1 \alpha$ and carbon substrate availability on mitochondrial function, OXPHOS, and gene expression of ETC components.

There is ample evidence that hypoxia alters mitochondrial function and oxygen utilization. ${ }^{8,9,43}$ HIF1 influences mitochondrial function by suppressing both the TCA cycle and respiration and controls mitochondrial biogenesis and autophagy. ${ }^{8,43}$ Few studies, however, have examined HIF1dependent changes in the expression of specific ETC genes. A Cox4 isoform exchange (Cox4i1 to Cox4i2) in response to hypoxia was reported to be coordinated by HIF1. HIF1 upregulates Cox4i2 mRNA expression and concurrently increases the level of Cox4il degradation through an increased level of expression of Lonp1, a mitochondrial protease. ${ }^{20}$ Our results show an upregulation of Lonp1 and Cox4i2, but the increased level of Cox4i2 was observed in Hifl $\alpha$ null, as well as, WT cells (Figures 3 and 4). These results are in agreement with a previously published report that also found that Cox4i2 is upregulated under hypoxia via a novel oxygen-responsive element (ORE) separate from an HRE. ${ }^{19,44}$ We observed a higher level of expression of Cox4i1 in both WT and Hifl $\alpha$ null cells grown with Gal, supporting the idea that Cox4i1 expression is independent of HIF $1 \alpha$. There is some indication that Cox4i2 is expressed in only certain tissues, while Cox4i1 is ubiquitously expressed and is the isoform responsible for ATP regulation of $\mathrm{CcO}$ activity. ${ }^{13,17,18}$

Our results indicate that Cox7a1 is a HIF1-regulated gene (Figures 3 and 4), and the $5000 \mathrm{bp}$ sequence on the mouse Cox7al gene (NC_00073.5:30964250 to $30969250 \mathrm{bp}$ ) prior to the start codon reveals at least six possible HREs. ${ }^{20}$ One of these HREs ( $5^{\prime}$-GCGTG-3') occurs within the 92 bp segment immediately upstream of the major transcription start site $(-80$ $\mathrm{bp}$ ), which in the bovine Cox7al gene is considered to be the basal promoter region responsible for most of the gene expression and activity. ${ }^{45}$ Evidence indicates that the level of Cox7a1 mRNA expression in human skeletal muscle decreases significantly with age and is positively related with glucose uptake, total body aerobic capacity, and PGC- $1 \alpha$ mRNA expression. $^{21}$ Cox7al knockout male mice displayed tissuespecific differences in resting ATP levels and reduced $\mathrm{CcO}$ specific activity and respiratory control ratio in skeletal muscle from wild-type mice. ${ }^{34,46}$ In addition, a significant increase in ROS production has been observed in response to Cox7a2 overexpression similar to the increased ROS production observed with the Cox4i2 replacement of Cox4i1 under nonhypoxic conditions. ${ }^{20}$ Because ROS is produced by the transfer of an electron to $\mathrm{O}_{2}$ at complex I or complex III, changes in $\mathrm{CcO}$ structure that produce ROS are most probably manifested by limitations in $\mathrm{CcO}$ activity. ${ }^{47}$ Moreover, cardiolipin, which interacts with COX7A near the site of the cytochrome $b c_{1}$ interface, is critical for $\mathrm{CcO}$ assembly and organizing components in supercomplexes and consequently improves $\mathrm{CcO}$ function. ${ }^{18}$ Taken together, this information shows a potential link among $\mathrm{Cox} 7 a$ subunits, $\mathrm{CcO}$ activity, and hypoxia, but further experimentation is needed to determine the impact of Cox $7 a$ subunit switching on supercomplex formation, ETC efficiency, and cellular energetics under various oxygen tensions in cell systems that express measurably levels of both Cox7a isoforms.

The $\mathrm{CcO}$ activity (Table 1 ) and cellular respiration (Figure 2 ) in Hif1 $\alpha$ null cells suggest that HIF $1 \alpha$ stabilization under hypoxia is necessary to maintain homeostasis in cellular oxidative metabolism. As previously described, cellular respiration was measured under nonhypoxic conditions and the respiration capacity in Hifl $\alpha$ null cells was not changed by a mitochondrial uncoupler with either carbon source while WT cells adapted to each nutrient type. $\mathrm{CcO}$ activity, however, was increased almost 3-fold in Hifl $\alpha$ null cells grown in Gal media following hypoxic stress. This increase was not observed in Hif1 $\alpha$ WT cells. These results suggest two things. First, the Hif1 $\alpha$ null cells are at maximal respiration normally. This inability to maintain spare respiratory capacity suggests the Hif $1 \alpha$ null cells are partially uncoupled or lack the necessary regulatory mitochondria-to-nuclear signaling to maintain reserve respiratory capacity. This might be partially explained by the upregulation of UCP4 in the null cells (Figure 2). This loss of spare respiratory capacity might also help explain why these cells lose mitochondrial mass under stress (i.e., hypoxia + GAL media). Second, HIF1 $\alpha$ plays a role in regulating overall $\mathrm{CcO}$ activity to maintain optimal efficiency and limit ROS generation. Galactose forces the cells to become more reliant on oxidative phosphorylation to meet energy demands, and 
hypoxia limits the cell's ability to produce ATP through complex IV. Under these conditions (i.e., hypoxia + GAL media), cells must modulate the efficiency of oxidative phosphorylation to maintain cellular energetics and limit oxidative stress. The results suggest that this adaptation is dependent upon $\mathrm{HIF} 1 \alpha$, and in its absence, $\mathrm{CcO}$ activity becomes unregulated and damages the mitochondria. This is evident from the increase in specific activity and the decrease in mitochondrial mass under these conditions. This might stem from the cell's inability to upregulate glycolytic capacity in the absence of $\mathrm{HIF} 1 \alpha$. Therefore, the higher $\mathrm{CcO}$ activity in $\mathrm{Hifl} \alpha$ null cells in Gal media under hypoxia shows an adapted response to cope with a stronger dependence on energy production via oxidative phosphorylation.

In conclusion, our study indicates a significant difference in oxygen utilization by Hif $1 \alpha$ WT and Hifl $\alpha$ null MEF cells in response to a mitochondrial uncoupler. These cell lines show differences in ETC gene expression profiles under different nutrient types and oxygen concentrations. Most importantly, we have identified HIF1 $\alpha$ as a regulator of $\mathrm{CcO}$ activity and Cox7al gene expression. Given their location within the crystal structure, we suggest a possible role for these hypoxia-induced isoform changes to translate into structural changes in a supercomplex formation depending on redox state or oxidative stress. Altogether, this study indicates that HIF $1 \alpha$ is critical for mitochondrial respiration control and transcriptional regulation of $\mathrm{CcO}$ components to achieve cellular adaptation in an oxygen-limiting environment.

\section{ASSOCIATED CONTENT}

\section{S Supporting Information}

Primer sets for reference, control, and selected genes for qPCR (Table S1). The Supporting Information is available free of charge on the ACS Publications website at DOI: 10.1021/ bi5012892.

\section{AUTHOR INFORMATION}

\section{Corresponding Author}

*E-mail: lapres@cns.msu.edu. Phone: (517) 432-9282.

\section{Present Address}

"S.G.L.: U.S. EPA, Office of Science Coordination and Policy, 1200 Pennsylvania Ave. NW (7203M), Washington, DC 20004. E-mail: lynn.scott@epa.gov.

\section{Author Contributions}

H.J.H. and S.G.L. contributed equally to this work.

\section{Funding}

This research was supported in part by Grant T32ES007255-19 from the National Institute of Environmental Health Sciences (NIEHS) to S.G.L. as a postdoctoral fellowship through the Michigan State University Center for Integrative Toxicology.

\section{Notes}

The authors declare no competing financial interest.

\section{ACKNOWLEDGMENTS}

Special thanks to Karen Studer-Rabeler and Coy Laboratory Products, Inc., for generously providing use of a Pre Sens Sensor Dish Reader along with extensive support and expertise. Dr. Jeff Landgraf and his staff at the Research Technology Support Facility (RTSF) at Michigan State University kindly provided access to and assistance with the Biomeck 2000 Laboratory Automation Workstation and ran the highthroughput 384-well qPCR plates. This material is based upon work partially supported by the National Institute of Food and Agriculture, U.S. Department of Agriculture (Project MICL01995).

\section{ABBREVIATIONS}

AHR, aryl hydrocarbon receptor; ARNT, aryl hydrocarbon receptor nuclear translocator; CCCP, carbonyl cyanide $m$ chlorophenylhydrazone; $\mathrm{CcO}$, cytochrome $c$ oxidase; DMSO, dimethyl sulfoxide; ETC, electron transport chain; Glc, glucose; Gal, galactose; HIF, hypoxia inducible factor; HREs, hypoxia response elements; MEF, mouse embryonic fibroblast; OXPHOS, oxidative phosphorylation; OCR, oxygen consumption rate; $\mathrm{PHDs}$, prolyl hydroxylase domain-containing proteins; TCA, tricarboxylic acid; qPCR, quantitative realtime polymerase chain reaction; HTP $\mathrm{qPCR}$, high-throughput quantitative real-time polymerase chain reaction; VDAC-1, voltage-dependent anion channel 1; WT, wild type.

\section{REFERENCES}

(1) Vengellur, A., Woods, B. G., Ryan, H. E., Johnson, R. S., and LaPres, J. J. (2003) Gene expression profiling of the hypoxia signaling pathway in hypoxia-inducible factor $1 \alpha$ null mouse embryonic fibroblasts. Gene Expression 11, 181-197.

(2) Ratcliffe, P. J. (2013) Oxygen sensing and hypoxia signalling pathways in animals: The implications of physiology for cancer. $J$. Physiol. 591, 2027-2042.

(3) Vengellur, A., and LaPres, J. J. (2004) The role of hypoxia inducible factor $1 \alpha$ in cobalt chloride induced cell death in mouse embryonic fibroblasts. Toxicol. Sci. 82, 638-646.

(4) Bunn, H. F., and Poyton, R. O. (1996) Oxygen sensing and molecular adaptation to hypoxia. Physiol. Rev. 76, 839-885.

(5) Shen, C., Nettleton, D., Jiang, M., Kim, S. K., and PowellCoffman, J. A. (2005) Roles of the HIF-1 hypoxia-inducible factor during hypoxia response in Caenorhabditis elegans. J. Biol. Chem. 280, 20580-20588.

(6) Li, Y., Padmanabha, D., Gentile, L. B., Dumur, C. I., Beckstead, R. B., and Baker, K. D. (2013) HIF- and non-HIF-regulated hypoxic responses require the estrogen-related receptor in Drosophila melanogaster. PLoS Genet. 9, e1003230.

(7) Taylor, C. T. (2008) Mitochondria and cellular oxygen sensing in the HIF pathway. Biochem. J. 409, 19-26.

(8) Solaini, G., Baracca, A., Lenaz, G., and Sgarbi, G. (2010) Hypoxia and mitochondrial oxidative metabolism. Biochim. Biophys. Acta 1797, 1171-1177.

(9) Palsson-McDermott, E. M., and O'Neill, L. A. (2013) The Warburg effect then and now: From cancer to inflammatory diseases. BioEssays 35, 965-973.

(10) Bruick, R. K. (2000) Expression of the gene encoding the proapoptotic Nip3 protein is induced by hypoxia. Proc. Natl. Acad. Sci. U.S.A. 97, 9082-9087.

(11) Rikka, S., Quinsay, M. N., Thomas, R. L., Kubli, D. A., Zhang, X., Murphy, A. N., and Gustafsson, A. B. (2011) Bnip3 impairs mitochondrial bioenergetics and stimulates mitochondrial turnover. Cell Death Differ. 18, 721-731.

(12) Gomes, A. P., Price, N. L., Ling, A. J., Moslehi, J. J., Montgomery, M. K., Rajman, L., White, J. P., Teodoro, J. S., Wrann, C. D., Hubbard, B. P., Mercken, E. M., Palmeira, C. M., de Cabo, R, Rolo, A. P., Turner, N., Bell, E. L., and Sinclair, D. A. (2013) Declining $\mathrm{NAD}^{+}$induces a pseudohypoxic state disrupting nuclear-mitochondrial communication during aging. Cell 155, 1624-1638.

(13) Huttemann, M., Kadenbach, B., and Grossman, L. I. (2001) Mammalian subunit IV isoforms of cytochrome c oxidase. Gene 267, $111-123$.

(14) Huttemann, M., Jaradat, S., and Grossman, L. I. (2003) Cytochrome $\mathrm{c}$ oxidase of mammals contains a testes-specific isoform of subunit VIb: The counterpart to testes-specific cytochrome c? Mol. Reprod. Dev. 66, 8-16. 
(15) Huttemann, M., Schmidt, T. R., and Grossman, L. I. (2003) A third isoform of cytochrome $c$ oxidase subunit VIII is present in mammals. Gene 312, 95-102.

(16) Pierron, D., Wildman, D. E., Huttemann, M., Markondapatnaikuni, G. C., Aras, S., and Grossman, L. I. (2012) Cytochrome c oxidase: Evolution of control via nuclear subunit addition. Biochim. Biophys. Acta 1817, 590-597.

(17) Acin-Perez, R., Gatti, D. L., Bai, Y., and Manfredi, G. (2011) Protein phosphorylation and prevention of cytochrome oxidase inhibition by ATP: Coupled mechanisms of energy metabolism regulation. Cell Metab. 13, 712-719.

(18) Arnold, S. (2012) The power of life: Cytochrome c oxidase takes center stage in metabolic control, cell signalling and survival. Mitochondrion 12, 46-56.

(19) Huttemann, M., Lee, I., Liu, J., and Grossman, L. I. (2007) Transcription of mammalian cytochrome $c$ oxidase subunit IV-2 is controlled by a novel conserved oxygen responsive element. FEBS $J$. 274, 5737-5748.

(20) Fukuda, R., Zhang, H., Kim, J. W., Shimoda, L., Dang, C. V., and Semenza, G. L. (2007) HIF-1 regulates cytochrome oxidase subunits to optimize efficiency of respiration in hypoxic cells. Cell 129, 111122.

(21) Ronn, T., Poulsen, P., Hansson, O., Holmkvist, J., Almgren, P., Nilsson, P., Tuomi, T., Isomaa, B., Groop, L., Vaag, A., and Ling, C. (2008) Age influences DNA methylation and gene expression of COX7A1 in human skeletal muscle. Diabetologia 51, 1159-1168.

(22) Chen, L., Xin, Z. C., Li, X., Tian, L., Yuan, Y. M., Liu, G., Jiang, X. J., and Guo, Y. L. (2006) Cox7a2 mediates steroidogenesis in TM3 mouse Leydig cells. Asian J. Androl. 8, 589-594.

(23) Ryan, H. E., Poloni, M., McNulty, W., Elson, D., Gassmann, M., Arbeit, J. M., and Johnson, R. S. (2000) Hypoxia-inducible factor- $1 \alpha$ is a positive factor in solid tumor growth. Cancer Res. 60, 4010-4015.

(24) Saini, Y., Harkema, J. R., and LaPres, J. J. (2008) HIF1 $\alpha$ is essential for normal intrauterine differentiation of alveolar epithelium and surfactant production in the newborn lung of mice. J. Biol. Chem. $283,33650-33657$.

(25) Lowry, O. H., Rosebrough, N. J., Farr, A. L., and Randall, R. J. (1951) Protein measurement with the Folin phenol reagent. J. Biol. Chem. 193, 265-275.

(26) Yang, T. T., Hsu, C. T., and Kuo, Y. M. (2009) Cell-derived soluble oligomers of human amyloid- $\beta$ peptides disturb cellular homeostasis and induce apoptosis in primary hippocampal neurons. J. Neural Transm. 116, 1561-1569.

(27) de Hoon, M. J., Imoto, S., Nolan, J., and Miyano, S. (2004) Open source clustering software. Bioinformatics 20, 1453-1454.

(28) Capaldi, R. A., Marusich, M. F., and Taanman, J. W. (1995) Mammalian cytochrome-c oxidase: Characterization of enzyme and immunological detection of subunits in tissue extracts and whole cells. Methods Enzymol. 260, 117-132.

(29) Thompson, D. A., and Ferguson-Miller, S. (1983) Lipid and subunit III depleted cytochrome $\mathrm{c}$ oxidase purified by horse cytochrome $\mathrm{c}$ affinity chromatography in lauryl maltoside. Biochemistry $22,3178-3187$.

(30) Naciri, M., Kuystermans, D., and Al-Rubeai, M. (2008) Monitoring $\mathrm{pH}$ and dissolved oxygen in mammalian cell culture using optical sensors. Cytotechnology 57, 245-250.

(31) Althoff, T., Mills, D. J., Popot, J., and Kuhlbrandt, W. (2011) Arrangement of electron transport chain components in bovine mitochondrial supercomplex $\mathrm{I}_{1} \mathrm{III}_{2} \mathrm{IV}_{1}$. EMBO J. 30, 4652-4664.

(32) Tsukihara, T., Aoyama, H., Yamashita, E., Tomizaki, T., Yamaguchi, H., Shinzawa-Itoh, K., Nakashima, R., Yaono, R., and Yoshikawa, S. (1996) The whole structure of the 13-subunit oxidized cytochrome c oxidase at $2.8 \AA$. Science $272,1136-1144$.

(33) Cui, T. Z., Conte, A., Fox, J. L., Zara, V., and Winge, D. R. (2014) Modulation of the respiratory supercomplexes in yeast: Enhanced formation of cytochrome oxidase increases the stability and abundance of respiratory supercomplexes. J. Biol. Chem. 289, $6133-6141$
(34) Huttemann, M., Klewer, S., Lee, I., Pecinova, A., Pecina, P., Liu, J., Lee, M., Doan, J. W., Larson, D., Slack, E., Maghsoodi, B., Erickson, R. P., and Grossman, L. I. (2012) Mice deleted for heart-type cytochrome $\mathrm{c}$ oxidase subunit 7al develop dilated cardiomyopathy. Mitochondrion 12, 294-304.

(35) Rodriguez-Enriquez, S., Juarez, O., Rodriguez-Zavala, J. S., and Moreno-Sanchez, R. (2001) Multisite control of the Crabtree effect in ascites hepatoma cells. Eur. J. Biochem. 268, 2512-2519.

(36) Rossignol, R., Gilkerson, R., Aggeler, R., Yamagata, K., Remington, S. J., and Capaldi, R. A. (2004) Energy substrate modulates mitochondrial structure and oxidative capacity in cancer cells. Cancer Res. 64, 985-993.

(37) Aguer, C., Gambarotta, D., Mailloux, R. J., Moffat, C., Dent, R., McPherson, R., and Harper, M. E. (2011) Galactose enhances oxidative metabolism and reveals mitochondrial dysfunction in human primary muscle cells. PLoS One 6, e28536.

(38) Forgacs, A. L., Burgoon, L. D., Lynn, S. G., LaPres, J. J., and Zacharewski, T. (2010) Effects of TCDD on the expression of nuclear encoded mitochondrial genes. Toxicol. Appl. Pharmacol. 246, 58-65.

(39) Pulliam, D. A., Deepa, S. S., Liu, Y., Hill, S., Lin, A. L., Bhattacharya, A., Shi, Y., Sloane, L., Viscomi, C., Zeviani, M., and Van Remmen, H. (2014) Complex IV-deficient Surf1 (-/-) mice initiate mitochondrial stress responses. Biochem. J. 462, 359-371.

(40) Oelkrug, R., Goetze, N., Meyer, C. W., and Jastroch, M. (2014) Antioxidant properties of UCP1 are evolutionarily conserved in mammals and buffer mitochondrial reactive oxygen species. Free Radical Biol. Med. 77, 210-216.

(41) Chandel, N. S. (2010) Mitochondrial regulation of oxygen sensing. Adv. Exp. Med. Biol. 661, 339-354.

(42) Chua, Y. L., Dufour, E., Dassa, E. P., Rustin, P., Jacobs, H. T., Taylor, C. T., and Hagen, T. (2010) Stabilization of hypoxia-inducible factor- $1 \alpha$ protein in hypoxia occurs independently of mitochondrial reactive oxygen species production. J. Biol. Chem. 285, 31277-31284.

(43) Papandreou, I., Cairns, R. A., Fontana, L., Lim, A. L., and Denko, N. C. (2006) HIF-1 mediates adaptation to hypoxia by actively downregulating mitochondrial oxygen consumption. Cell Metab. 3, 187-197.

(44) Aras, S., Pak, O., Sommer, N., Finley, R., Jr., Huttemann, M., Weissmann, N., and Grossman, L. I. (2013) Oxygen-dependent expression of cytochrome c oxidase subunit 4-2 gene expression is mediated by transcription factors RBPJ, CXXC5 and CHCHD2. Nucleic Acids Res. 41, 2255-2266.

(45) Seelan, R. S., Gopalakrishnan, L., Scarpulla, R. C., and Grossman, L. I. (1996) Cytochrome c oxidase subunit VIIa liver isoform. Characterization and identification of promoter elements in the bovine gene. J. Biol. Chem. 271, 2112-2120.

(46) Lee, I., Huttemann, M., Liu, J., Grossman, L. I., and Malek, M. H. (2012) Deletion of heart-type cytochrome $c$ oxidase subunit $7 \mathrm{a} 1$ impairs skeletal muscle angiogenesis and oxidative phosphorylation. J. Physiol. 590, 5231-5243.

(47) Chen, Q., Vazquez, E. J., Moghaddas, S., Hoppel, C. L., and Lesnefsky, E. J. (2003) Production of reactive oxygen species by mitochondria: Central role of complex III. J. Biol. Chem. 278, 3602736031. 